\title{
MIEJSCE I ROLA BIBLIOTEK ZAKLADOWYCH W SYSTEMIE NAUKOWO-DYDAKTYCZNYM I INFORMACYJNYM SZKOLY WYŻSZEJ NA PRZYKŁADZIE SIECI BIBLIOTECZNEJ UNIWERSYTETU LÓDZKIEGO ZARYS PROBLEMATYKI
}

\begin{abstract}
This paper examines the issue of creating the library network at the University of Łódź, and indicates department libraries' place and role in the academic environment. The seventy-year history of the University of Łódź shows that creating academic library is a difficult task, despite the actual needs of the environment in this respect. The created library network of the University of Łódź, which consists of The Library of University of Łódź and Department Libraries, takes part in fulfilling basic responsibilities of the higher education. Academic library has to fulfil the key tasks in the academic environment, it means that providing fast access to the information, which is essential to the execution of scientific-didactic processes of the University, and simultaneously is necessary to organize the most perfect workroom for scientificdidactic tasks conducted by academic teachers. It is facilitated by the fact that there exist perfect narrowly specialized book collections in Department Libraries. Moreover, the collected faculty didactic literature increases the importance of special libraries for realisation of syllabuses by particular faculties of the University.
\end{abstract}

Słowa kluczowe: biblioteka akademicka, sieć biblioteczna, księgozbiór specjalistyczny, nauczanie akademickie

\section{Powstanie Bibliotek Zakładowych Uniwersytetu Lódzkiego}

Uniwersytet Łódzki (UŁ) obchodzi w 2015 r. swoje siedemdziesięciolecie. Oficjalnie został powołany do życia Dekretem z dnia 24 maja 1945 r. ${ }^{1}$, choć pomysł zorganizowania po II wojnie światowej w Łodzi uczelni typu uniwersyteckiego narodził się jeszcze w latach okupacji ${ }^{2}$. Łódź, ośrodek przemysłowy, w pierwszych latach powojennych zastępowała zniszczoną stolicę, także jako ośrodek kultury. Miasto bez większych tradycji akademickich, dorobku naukowego, bez ugruntowanego środowiska intelektualnego, rozpoczynając

${ }^{1}$ Uniwersytet Lódzki [24 maja 1945 - 24 maja 2000]: refleksje nad dziejami i dorobkiem Uczelni] = University of Łódź [24th May, 1945 - 24th May], 2000: reflections on the history and achievements of the University, komitet red. S. Liszewski [et al.], Łódź 2000, s. 5.

${ }^{2}$ B. Baranowski, K. Baranowski, Pierwsze lata Uniwersytetu Lódzkiego (1945-1949), Łódź 1985, s. 20. 
budowę wyższych uczelni, próbowało ściągnąc wybitnych uczonych z przedwojennych ośrodków akademickich: z Warszawy, Lwowa, Krakowa i innych, tworzyć instytucje i towarzystwa naukowe. Należało wówczas pamiętać, iż wszystkie te ambitne plany byłyby niemożliwe bez dostępu do książek i bibliotek, które obok kadry naukowej były drugim, równie ważnym, elementem składowym tworzącej się uczelni. Ich brak zawsze wpływał hamująco na rozwój życia naukowego.

Początkowo ścierały się różne koncepcje dotyczące realizacji projektu Uniwersytetu pomiędzy Bolesławem Wilanowskim (zwolennik megauniwersytetu), a Teodorem Viewegerem (zwolennik założeń przedwojennej Wolnej Wszechnicy Polskiej), którzy pracowali w Łodzi już od stycznia 1945 r. $^{3}$ Ostatecznie tworząca się uczelnia wykorzystała dorobek i tradycje działających w okresie międzywojennym w Łodzi: Instytutu Nauczycielskiego (1921-1928), Wyższej Szkoły Nauk Społecznych i Ekonomicznych (1924-1928) oraz oddziału Wolnej Wszechnicy Polskiej (1928-1939). Pozwoliło to zainaugurować rok akademicki 1945/1946 w UŁ sześciu wydziałom: Uczelnia cały swój wysiłek kierowała wówczas na organizowanie poszczególnych zakładów, jako jednostek dydaktycznych. Kolejne lata przyniosły liczne zmiany organizacyjne. Losy UŁ determinowały nie tylko uwarunkowania polityczne, jak na przykład wydarzenia 1956 r. i 1970 r., czy czasy transformacji ustrojowej z nową ustawą o szkolnictwie wyższym z 1990 r. ${ }^{5}$, ale równie często dynamika rozwoju różnych dziedzin nauki. Dość powiedzieć, że swój jubileusz UŁ może świętować, jako duża, nowoczesna i licząca się uczelnia $\mathrm{z}$ dwunastoma wydziałami.

Jednocześnie z tworzeniem Uniwersytetu dostrzeżono konieczność zapewnienia środowisku akademickiemu biblioteki o charakterze naukowym, jako niezbędnej komórki organizacyjnej, pomocnej w dostępie do podstawowego narzędzia pracy naukowo-dydaktycznej, czyli literatury naukowej. W związku z tym Komitet Organizacyjny Uczelni Państwowej w Łodzi w dniu 11 lutego 1945 r. powołał do życia Bibliotekę Uniwersytecką. Oficjalnie stan personelu powstałej wówczas placówki liczył trzech pracowników ${ }^{6}$. Od razu przystąpiono do pozyskiwania książek dla Biblioteki. Biblioteka Uniwersytecka jest więc starszą siostrą i jednocześnie równolatką Uniwersytetu Łódzkiego. W 2015 r. również obchodzi swoje siedemdziesiąte urodziny.

W pierwszych latach istnienia Uniwersytetu dało się zauważyć ogromne zaangażowanie kadry naukowej $\mathrm{w}$ tworzenie uczelni jako własnego warsztatu pracy, ale również studentów, którzy wykazywali niezwykłą chęć zdobywania wiedzy, uczestnictwa w wykładach i głód książki, a zwłaszcza podręczników.

\footnotetext{
${ }^{3}$ Uniwersytet Łódzki..., op. cit, s. 7-8.

${ }^{4}$ B. Baranowski, K. Baranowski, op. cit., s. 35.

${ }^{5}$ Ustawa z dnia 12 września 1990 r. o szkolnictwie wyższym, „Dziennik Ustaw” 1990, nr 65 , poz. 385 .

${ }^{6} \mathrm{H}$. Więckowska, Biblioteka Uniwersytecka, [w:] Materiały do dziejów Uniwersytetu Łódzkiego (1945-1950), red. B. Baranowski, K. Duda-Dziewierz, Łódź 1952, s. 116.
} 
Nic więc dziwnego, iż obok utworzonej Biblioteki Głównej UŁ niemal jednocześnie zaczęły powstawać księgozbiory przy tworzących się dydaktycznonaukowych jednostkach organizacyjnych uczelni. Wymagało to wielokierunkowych działań organizacyjnych, nakładów finansowych i sprecyzowania zasad polityki gromadzenia zbiorów. Początki zawsze bywają trudne, zważywszy na fakt braku lokali, ale i z racji niedostatku samych książek, czy podstawowego aparatu informacyjnego tworzonych placówek. W takich warunkach nie mogły one sprostać jednej z podstawowych form działalności, jaką było udostępnianie zbiorów. Prace związane z tworzeniem owych placówek dziedzinowych wykonywali początkowo asystenci i adiunkci w ramach swoich obowiązków, obok zajęć dydaktycznych i naukowych. Powstające w takich warunkach zalążki bibliotek nie tylko nie posiadały etatowych pracowników, ale i fachowców mogących owe zasoby opracować i w odpowiedzialny sposób udostępniać. Niedostatek wyspecjalizowanego personelu bibliotecznego doskwierał $\mathrm{w}$ owym czasie również Bibliotece Głównej, ale od samego początku swojego istnienia służyła ona pomocą merytoryczną i poradami wszystkim jednostkom gromadzącym księgozbiory specjalistyczne w uczelni. Można powiedzieć, że tworzyła się w ten sposób ogólnouczelniana sieć biblioteczna, na którą złożyły się biblioteki specjalistyczne wspólnie z Biblioteką Główną Uniwersytetu Łódzkiego (BUŁ).

Wzorem organizacji placówek stały się istniejące w kraju biblioteki naukowe. W maju 1945 r. zasoby BUŁ liczyły około 70 tysięcy tomów, a 1 października 1946 r. już blisko 300 tysięcy tomów ${ }^{7}$. W tym czasie sprawy biblioteczne w kraju porządkował podstawowy akt prawny - Dekret o bibliotekach i opiece nad zbiorami bibliotecznymi z 17 kwietnia 1946 r. zapewniający utrzymanie bibliotek przez państwo i uznający ich księgozbiory za narodowe mienie kulturalne ${ }^{8}$. Biblioteka otrzymała również prawo do egzemplarza obowiązkowego ${ }^{9}$.

W swoim założeniu zarówno BUŁ, jak i biblioteki instytutowe czy katedralne powstawały jako placówki o charakterze naukowym, a ich zadaniem miało być zapewnienie zaplecza naukowo-badawczego dla pracowników UŁ pod kątem prac prowadzonych przez kadrę naukowo-dydaktyczną. Jednocześnie miały one za zadanie gromadzenie księgozbioru dydaktycznego zapewniającego studentom możliwość dotarcia do podręczników i wydawnictw wykorzystywanych podczas zajęć seminaryjnych. Do uzyskania potrzebnych informacji lub zdobywania kolejnego szczebla wykształcenia niezbędne jest czytanie literatury fachowej. Konieczność dostosowywania zasobów do szybko rozwijających się specjalizacji poszczególnych jednostek organizacyjnych Uczelni doprowadziła do powstania księgozbiorów o różnorodnej tematyce.

\footnotetext{
${ }^{7}$ B. Baranowski, K. Baranowski, op. cit., s. 212.

${ }^{8}$ Dekret o bibliotekach... z dnia 17 kwietnia 1946 r., „Dziennik Ustaw” 1946 nr 26, poz. 163.

${ }^{9}$ H. Więckowska, op. cit., s. 124.
} 
Rozwój bibliotek specjalistycznych zwanych bibliotekami zakładowymi (BZ) był niezwykle zróżnicowany. Niektóre katedry dysponowały znacznymi zbiorami, ale były i takie, które ich nie miały wcale lub niewiele. Z największym rozmachem rozbudowywane były biblioteki: Instytutu Historycznego i Instytutu Socjologicznego, ale również Katedry Historii Literatury Polskiej, Katedry Języka i Literatury Rosyjskiej, czy Katedry Geografii ${ }^{10}$. Powiększanie zbiorów, w pierwszym okresie istnienia tych placówek, napotykało na wiele trudności i powodzenie takiego przedsięwzięcia zależało od operatywności zatrudnionych tam pracowników, ich energii i osobistego zaangażowania. $\mathrm{Na}$ niezbędne zakupy przeznaczano bardzo skromne środki. Źródłem nabytków często były dary lub, jak na przykład w przypadku Biblioteki Instytutu Historycznego, pozyskanie księgozbioru Oddziału Łódzkiego Wolnej Wszechnicy Polskiej czy ściągnięcie zasobów kilku bibliotek podworskich ${ }^{11}$.

By pomóc w prawidłowym funkcjonowaniu BZ w latach 1949-1950 zorganizowano w BUŁ kursy z ćwiczeniami i praktyki dla asystentów UŁ zajmujących się prowadzeniem BZ. Opracowano nawet Wskazówki dla bibliotek zakładowych ${ }^{12}$. W 1949 r. przeszkolono łącznie 34 osoby z BZ ${ }^{13}$. Z zasobu skatalogowanego łącznie we wszystkich placówkach bibliotecznych UŁ 60\% znajdowało się w BUŁ, zaś 40\% w BZ, co sprawiało, że kadra naukowa częściej wykorzystywała księgozbiory BZ niż Biblioteki Uniwersyteckiej ${ }^{14}$.

$\mathrm{Z}$ czasem powołano w BUŁ osobną jednostkę organizacyjną odpowiedzialną za sprawy BZ. 19 czerwca 1954 r. Ministerstwo Szkolnictwa Wyższego wydało Instrukcje $w$ zakresie działania sieci bibliotecznej szkoły wyższej, co umożliwiało Bibliotece Głównej prawo ingerencji w sprawy organizacji BZ tak, by rosnące księgozbiory zostały opracowane, zaś te nie mające możliwości uporządkowania, zlikwidowane. W 1955 r., po 10 latach funkcjonowania UŁ, na 47 istniejących BZ tylko w czterech: Instytutu Historycznego, Katedry Historii i Literatury Polskiej, Katedry Historii Myśli Społecznej i Zakładu Teorii Państwa i Prawa, poza asystentami, zaangażowany był specjalny pracownik biblioteczny w pełnym wymiarze godzin, zaś we wszystkich innych zakładach zatrudnieni byli jedynie dorywczo pracownicy godzinowi ${ }^{15}$. W $1956 \mathrm{r}$. powstał Oddział Bibliotek Zakładowych Uniwersytetu Łódzkiego (OBZ UŁ). Nie tylko doceniono rolę księgozbiorów gromadzonych poza Biblioteką Główną, lecz podjęto działania scalania rozdrobnionych zasobów na rzecz tworzenia większych, lepiej zorganizowanych bibliotek. Funkcjonowanie BZ oparto

\footnotetext{
${ }^{10}$ B. Baranowski, K. Baranowski, op. cit., s. 215.

${ }^{11}$ Ibidem.

${ }^{12}$ Wskazówki dla bibliotek zakładowych Ut, [oprac. J. Racięcka przy współudziale I. Treichel], Łódź 1951.

${ }^{13}$ Sprawozdanie Biblioteki Uniwersyteckiej w Lodzi za czas od 1 IX 1948 do 31 XII 1949, Łódź 1950, s. 10.

${ }^{14}$ B. Baranowski, K. Baranowski, op. cit., s. 216.

${ }^{15}$ Sprawozdanie Biblioteki Uniwersyteckiej w Lodzi za rok 1955, Łódź 1956, s. [54]-55.
} 
na wewnętrznych regulaminach poszczególnych bibliotek określając zasady udostępniania zbiorów oraz współpracy z innymi jednostkami organizacyjnymi poszczególnych wydziałów.

Równie ważne jak gromadzenie zbiorów było stworzenie sytemu katalogów. Rolą katalogów jest kompletne zestawienie wszystkich wydawnictw znajdujących się $\mathrm{w}$ bibliotece $\mathrm{w}$ formie opisów bibliograficznych wraz $\mathrm{z}$ odsyłaczami szczegółowymi. Dopełnieniem znajdujących się już w BUŁ katalogów stał się więc Centralny Katalog Bibliotek Zakładowych (CKBZ). Zawierał on alfabetyczny zbiór kopii kart katalogowych wydawnictw zwartych i ciągłych wszystkich BZ (bez odsyłaczy). Kompletność CKBZ podnosiła wówczas jego wartość informacyjną i umożliwiała właściwą współpracę międzybiblioteczną. Kiedy zarządzeniem Ministra Szkolnictwa Wyższego w 1961 r., włączono oficjalnie nową strukturę BZ do ogólnouczelnianej sieci bibliotek ${ }^{16}$, możliwy stał się dalszy rozwój tych placówek. Pozwoliło to jednocześnie usankcjonować prawnie istnienie samego OBZ w BUŁ oraz, co równie ważne, można było wyodrębnić etaty biblioteczne dla Bibliotek Instytutowych czy Wydziałowych. Zarzadzenie Rady Ministrów z dn. 27 sierpnia 1966 r. w sprawie uposażeń pracowników stużby bibliotecznej pozwoliło na zatrudnienie w BZ bibliotekarzy ${ }^{17}$. Profil gromadzonych wydawnictw wyznaczyły bibliotekom programy nauczania i kierunki prowadzonych prac naukowo-badawczych w poszczególnych jednostkach organizacyjnych UŁ. Tak sprecyzowane założenia polityki gromadzenia zbiorów stały się przedmiotem wyjątkowej troski bibliotekarzy. BZ mogły więc stanowić specjalistyczną bazę źródeł informacji niezbędną w bieżącej pracy zarówno nauczycieli akademickich, jak i studentów. Zadaniem BZ pozostawała głównie obsługa własnej jednostki macierzystej i studentów określonych kierunków i specjalizacji. W miarę rozwoju rynku wydawniczego zaczęto dążyć do kompletowania literatury specjalistycznej z dziedzin wiedzy reprezentowanych przez Wydziały, Instytuty czy Katedry, a księgozbiory poszczególnych jednostek powiększały się zarówno o druki zwarte, jak i czasopisma, polskie i obce. Obok wydawnictw podstawowych gromadzono również literaturę z nauk pomocniczych i pokrewnych dla danej dziedziny wiedzy. Do cenionych pozycji bibliotecznych zawsze należały czasopisma naukowe i to nie tylko ze względu na ich szeroki zakres tematyczny, ale również wartość merytoryczną i aktualność. Czasopisma naukowe traktowane przez środowisko akademickie jako podstawowa forma upowszechniania osiągnięć nauki zawsze zapewniały szybki dopływ informacji. BZ dbały więc o gromadzenie bogatych liczbowo zasobów czasopiśmienniczych. Rozwój BZ determinowały często nie

${ }^{16}$ Zarzadzenie Ministra Szkolnictwa Wyższego z dnia 18 marca 1961 r. w sprawie struktury organizacyjnej i zasad działania biblioteki głównej szkoły wyższej oraz bibliotek przy poszczególnych jednostkach organizacyjnych szkół wyższych podlegtych Ministrowi Szkolnictwa Wyższego, „Dziennik Urzędowy Ministerstwa Spraw Wewnętrznych” 1961, nr 3, poz. 9.

${ }^{17}$ Zarządzenie Rady Ministrów z dnia 27 sierpnia 1966 r., „,Dziennik Ustaw” 1966, nr 37, poz. 225. 
finanse, a odwieczny problem ograniczonych powierzchni lokalowych. Ciasnota w magazynach zmuszała bibliotekarzy zarówno do pracochłonnej selekcji zbiorów, jak i uszczuplania zakupów bieżących.

Zaletą BZ, najczęściej podkreślaną przez czytelników, był niewątpliwie szybszy dostęp do wyselekcjonowanych treści zgodnych z profilem biblioteki oraz krótsza droga książki od biblioteki do czytelnika. W latach siedemdziesiątych XX w. zapadła decyzja o reorganizacji BZ. Jej celem było tworzenie silniejszych jednostek poprzez scalanie mniejszych księgozbiorów. Sprzyjała temu nowa struktura UŁ wprowadzająca od 30 września 1970 r. instytut jako podstawową jednostkę organizacyjną. Trudnością w przeprowadzeniu owych zamierzeń był jednak fakt, że wiele Katedr i Zakładów UŁ traktowało swoje zbiory, jak swoiste biblioteki podręczne i nie zamierzały się ich pozbywać.

Warto w tym miejscu zaznaczyć, że właśnie wówczas kształtu nabierały biblioteki, które dysponowały miejscami w czytelniach i to one dźwigały główny ciężar obsługi czytelników. To tam odnotowywany był ciągły wzrost wskaźników udostępniania. W 1965 r. w sieci BZ działało 8 bibliotek posiadających łącznie 284 miejsca w czytelniach. Tylko te placówki udostępniły na miejscu i poza obręb biblioteki 214639 vol. na 241472 vol. udostępnionych łącznie we wszystkich 74 jednostkach $^{18}$, zaś po kolejnych 10 latach, czyli w 1975 r., na 70 istniejących placówek w sieci funkcjonowało 13, które posiadały czytelnie. Tego roku na liczbę 549954 vol. książek wypożyczonych ogółem - 470611 vol. (blisko 86\%) przypadło na wspomniane 13 wiodących bibliotek $^{19}$. W 1985 r. na podobnym poziomie $86 \%$ skoncentrowało się udostępnianie w $16 \mathrm{BZ}$ posiadających czytelnie ${ }^{20}$.

\section{W stronę automatyzacji}

Pierwsze pomysły automatyzacji BUŁ miały miejsce na początku lat siedemdziesiątych XX w., kiedy w Polsce planowano stworzenie ogólnokrajowego systemu informacji naukowo-technicznej (SINTO). Zamysł ten nie doczekał się realizacji i dopiero w 1984 r. wrócono do sprawy komputeryzacji BUŁ poprzez planowany zakup opracowanego i wdrożonego w Politechnice Wrocławskiej (PW) zautomatyzowanego systemu rejestracji dorobku naukowego pracowników PW na nośniku SINT/NB ${ }^{21}$. Niestety idea ta utknęła na etapie uzgodnień i tekstu umowy, gdyż zatrudnieni w międzyczasie informatycy BUŁ zaproponowali zaprojektowanie, w oparciu o system wrocławski, własnego systemu na uczelnianym sprzęcie SYNABA-SINT/NB dla $\mathrm{UL}^{22}$.

\footnotetext{
${ }^{18}$ XX sprawozdanie Biblioteki Uniwersyteckiej w Lodzi za rok 1965, Łódź 1966, s. 63.

${ }^{19}$ XXX sprawozdanie Biblioteki Uniwersyteckiej w Lodzi za rok 1975, Łódź 1977, s. 53.

${ }^{20}$ Ibidem, s. 70.

${ }^{21} \mathrm{~J}$. Andrzejewski, Prace nad automatyzacja procesów Biblioteczno-informacyjnych w BUL, [w:] XL-XLI sprawozdanie Biblioteki Uniwersyteckiej w Lodzi za lata 1985-1986, Łódź 1989 , s. 36.

${ }^{22}$ Ibidem, s. 37.
} 
Nieporozumienia kadrowo-płacowe i sprzętowe doprowadziły jednak do odejścia informatyków z pracy w BUŁ i zaniechania dalszych działań w tym zakresie. Próby te, choć zakończone niepowodzeniem, pozwoliły spojrzeć na potrzebę komputeryzacji w szerszym kontekście i wzięcie pod uwagę docelowo wszystkich procesów bibliotecznych obejmujących BUŁ i jej sieć. W BZ zaczęły pojawiać się pojedyncze komputery służące głównie do tworzenia własnych baz i tu za przykład może posłużyć Biblioteka Wydziału Prawa i Administracji, która jako jedna z pierwszych została wyposażona w komputer PC IBM/XT już w 1989 r.

Tabela 1

Liczba pracowników, bibliotek, stan księgozbioru na dzień 31.12. danego roku oraz udostępnianie w BZ UŁ w latach 1955, 1965, 1975, 1985.

\begin{tabular}{|c|c|c|c|c|c|}
\hline Rok & $\begin{array}{c}\text { Liczba } \\
\text { pracowników } \\
\text { w BZ }\end{array}$ & $\begin{array}{c}\text { Liczba } \\
\text { BZ }\end{array}$ & $\begin{array}{c}\text { Stan księgozbioru } \\
\text { BZ (lącznie vol.) }\end{array}$ & $\begin{array}{c}\text { Liczba } \\
\text { odwiedzin } \\
\text { w BZ }\end{array}$ & $\begin{array}{c}\text { Liczba } \\
\text { vol. } \\
\text { lącznie } \\
\text { udostępnionych } \\
\text { w BZ }\end{array}$ \\
\hline 1955 & $4^{a}$ & 47 & 399227 & 68627 & 109022 \\
\hline 1965 & $59^{b}$ & 74 & 340000 & 103890 & $241472^{c}$ \\
\hline 1975 & $65^{d}$ & 70 & 638159 & 150821 & 549954 \\
\hline 1985 & $88^{e}$ & 67 & 841762 & 108140 & 487771 \\
\hline
\end{tabular}

Źródło: Sprawozdania Biblioteki Uniwersyteckiej w Łodzi za poszczególne lata.

${ }^{a} \mathrm{~W}$ bibliotekach Instytutu Historycznego, Katedry Historii i Literatury Polskiej, Katedry Historii Myśli Społecznej i Zakładu Teorii Państwa i Prawa zaangażowany był pracownik biblioteczny na pełen etat, a we wszystkich Zakładach poza Wydziałem Prawa pracowali tylko dorywczo pracownicy godzinowi. Zob.: Sprawozdanie Biblioteki Uniwersyteckiej w Lodzi za rok 1955, Łódź 1956, s. 54-55.

${ }^{b} \mathrm{Na}$ tę liczbę składają się 23 etaty w bibliotekach zakładowych i 26 osób na etatach płatnych z funduszu na prace zlecone. Zob. XX sprawozdanie Biblioteki Uniwersyteckiej $w$ Łodzi za rok 1965, Łódź 1966, s. 58.

${ }^{c}$ Duże braki kadrowe w BZ przerastały możliwości dotychczasowego personelu.

${ }^{d} \mathrm{Na}$ tę liczbę składa się 59 etatów BUŁ, 6 etatów Instytutów UŁ. Pomagało również 5 osób płatnych z bezosobowego funduszu na prace zlecone. Zob. $X X X$ sprawozdanie Biblioteki Uniwersyteckiej w Lodzi za rok 1975, Łódź 1977, s. 50.

${ }^{e} \mathrm{Na}$ ogólną liczbę pracowników składa się: 81 osób w tym 4 na 1/2 etatu i 7 osób na etatach zakładów. Zob.: XL-XLI sprawozdanie Biblioteki Uniwersyteckiej w Lodzi za lata 1985-1986, Łódź 1989, s. 68.

Dopiero w latach dziewięćdziesiątych XX w. wprowadzono w bibliotekach UŁ nowe technologie. Rozpoczęto zamykanie katalogów kartkowych (początkowo w BUŁ, następnie w sieci bibliotecznej UŁ) i przechodzenie do ogólnouczelnianego katalogu komputerowego. Kluczowym momentem dla rozwoju komputeryzacji na tym etapie było ustawiczne kształcenie zatrudnionych bibliotekarzy pozwalające na urzeczywistnienie automatyzacji procesów 
bibliotecznych. Jako pierwsi dokształcali się bibliotekarze BUŁ, oni bowiem wdrażali nowe technologie. W dalszej kolejności mieli być szkoleni etatowi bibliotekarze pracujący poza Biblioteką Główną. Problemem pozostawały placówki, które nie posiadały etatowych pracowników, a gromadziły księgozbiory.

Zintegrowany system biblioteczny Horizon został wdrożony w $1998 \mathrm{r}$. w BUŁ oraz jednocześnie $\mathrm{w}$ innych bibliotekach łódzkich zrzeszonych w Łódzkiej Akademickiej Sieci Bibliotecznej. Tylko kwestią czasu i pieniędzy na niezbędny sprzęt $\mathrm{i}$ infrastrukturę pozostawało włączenie $\mathrm{BZ} \mathrm{w}$ zainicjowane procesy. Priorytetem było stworzenie programu współkatalogowania dla wszystkich bibliotek UŁ. Jednocześnie chodziło o utrzymanie jednolitego systemu biblioteczno-informacyjnego uczelni, w skład którego wchodziła BUŁ oraz biblioteki poszczególnych jednostek organizacyjnych.

U progu drugiego tysiąclecia w UŁ istniało ogółem 100 BZ: 3 - wydziałowe, 5 - kierunkowych, 10 - instytutowych, 61 - katedr, 11 - zakładów, 1 - kolegium, 1 - laboratorium, 1 - centrum ${ }^{23}$. Nie licząc początkowej pomocy ze strony BUŁ, cały ciężar szkolenia pracowników BZ z zakresu obsługi modułu katalogowania, pracy w formacie MARC 21 i nadzoru nad bibliotekami sieci spadł na OBZ.

W międzyczasie, w UŁ zainicjowano nowe kierunki studiów, co zwiększyło grono studiujących $\mathrm{w}$ porównaniu do lat wcześniejszych. Powołano Wydział Zarządzania wraz z biblioteką, w 1998 r. utworzono Filię UŁ w Tomaszowie Mazowieckim oraz dydaktyczne ośrodki zamiejscowe w Kutnie, Ostrołęce, Piotrkowie Trybunalskim, Sieradzu i Skierniewicach. W 2000 r. utworzono Wydział Studiów Międzynarodowych i Politologicznych oraz w 2001 r. Wydział Nauk Geograficznych ${ }^{24}$. Był to również rok projektowania i przygotowań do przystąpienia do zintegrowanego ogólnouczelnianego systemu bibliotecznego Horizon w pierwszych siedmiu BZ. Zabezpieczono w nich odpowiedni sprzęt komputerowy i pieniądze na zakup licencji Horizon, a następnie zezwolono na faktyczne tworzenie wspólnego z BUŁ katalogu komputerowego. Były to biblioteki: Polonistyczna, Instytutu Anglistyki, Wydziału Ekonomiczno-Socjologicznego, Geograficzna, Fizyczna i Wydziału Matematyki. W ciągu kilku następnych lat liczba bibliotek prowadzących katalog komputerowy ciągle rosła, obciążając personel OBZ wszystkimi obowiązkami związanymi $\mathrm{z}$ wdrażaniem współkatalogowania $\mathrm{w}$ sieci bibliotecznej UŁ. Następstwem takiego natłoku obowiązków pracowników OBZ było zrezygnowanie z pomocy bibliotekom nie posiadającym etatowego personelu ze świadomością, iż owe podręczne księgozbiory nie mają szans na włączenie ich do systemu i z czasem mogą zostać zlikwidowane. Z końcem 2007 r. zamknięto również CKBZ.

${ }^{23}$ Informator Oddziału Bibliotek Zakładowych na rok 2001, Łódź 2001.

${ }^{24}$ Historia Uniwersytetu Eódzkiego, [dostęp: 19.01.2015], http://www.uni.lodz.p1/ouni/ historia. 
Prężnie rozwijające się technologie informacyjne zaczęły dostarczać narzędzi - sprzętu oraz oprogramowania - umożliwiających pozyskiwanie informacji, jej selekcję, analizowanie, przetwarzanie czy zarządzanie. Pokonanie barier czasu i przestrzeni, stworzenie warunków do jednakowego dostępu do wiedzy i informacji, pozwoliło ułatwić codzienne funkcjonowanie i permanentną edukację środowisku akademickiemu, które stanowi specyficzną część współczesnego społeczeństwa wiedzy i informacji. Dostęp do sieci, do Internetu, to dostęp do szybkiego i skutecznego aparatu informacyjnego, a w kontekście biblioteki podniesienie jej atrakcyjności. Intensywna praca związana z komputeryzacją sieci nie mogła jednak wpływać na bieżące funkcjonowanie bibliotek dziedzinowych i obsługę czytelników. Wymagało to ogromnego zaangażowania zatrudnionego tam personelu, zrozumienia ze strony władz poszczególnych Wydziałów, by stworzone warunki były korzystne zarówno pod względem finansowym, jak i lokalowym, umożliwiając dalszy rozwój tych placówek. W niektórych udało się przeprowadzić niezbędne remonty, a kilka otrzymało nowe pomieszczenia biblioteczno-magazynowe między innymi Biblioteka Polonistyczna Wydziału Filologicznego, Katedry Bibliotekoznawstwa i Informacji Naukowej, Instytutu Anglistyki, Instytutu Filozofii czy Instytutu Historii. Biblioteki sieci nie odnotowały spadku, a wręcz wzrost wskaźników gromadzenia i udostępniania zbiorów, zaś czytelnicy otrzymali dodatkowo możliwość wglądu do zasobów bibliotecznych korzystając z dostępnych online katalogów komputerowych swoich bibliotek dziedzinowych. Poszczególne placówki sukcesywnie zaczęły zamykać swoje katalogi kartkowe i skoncentrowały się na szybkim wprowadzaniu bieżących nabytków oraz retrospektywnym katalogowaniu zbiorów, wykorzystując możliwość dołączania gotowych rekordów bibliograficznych. W dalszej perspektywie zaplanowane było stopniowe podłączanie w BZ kolejnych modułów sytemu, a zwłaszcza modułu udostępniania, najbardziej oczekiwanego przez użytkowników. Ciągły przyrost liczby opisów bibliograficznych we wspólnej bazie spowodował częstsze ich wykorzystywanie przez czytelników. Również wprowadzenie i wdrożenie w Bibliotece Wydziału Nauk o Wychowaniu i Bibliotece Wydziału Nauk Geograficznych modułu udostępniania otworzyły czytelnikom tych placówek nowe możliwości.

Trudnym dla sieci bibliotecznej UŁ okazał się 2010 r., kiedy zgodnie z zaplanowaną strategią rozwoju uczelni na kolejne 5 lat nastąpiła decentralizacja finansowania poszczególnych Wydziałów Uniwersytetu. Uczelnia musiała uporać się nie tylko z niżem demograficznym, a co za tym idzie, ciągle malejącą liczbą studentów; lecz również z ogromnymi długami na wielu Wydziałach. Zaległości finansowe niewątpliwie ciążyły na codziennym funkcjonowaniu zadłużonych jednostek organizacyjnych UŁ. Jednocześnie wzrosły prerogatywy Dziekanów poszczególnych Wydziałów w zakresie dysponowania środkami finansowymi oraz prowadzenia polityki kadrowej. Skutki takiej sytuacji odbiły się na działalności sieci bibliotecznej uczelni. Zapadły decyzje o redukcjach etatów bibliotecznych w BZ. W widoczny sposób fakty te odbiły się 
niekorzystnie na organizacji pracy w sieci. Poszczególne placówki zmuszone były w tym układzie do weryfikacji godzin pracy i wprowadzenia zmian, bądź to poprzez skrócenie czasu pracy agend lub całej biblioteki, rezygnację z dyżurów popołudniowych, ograniczenie sobotnich dyżurów do dni zjazdów studentów zaocznych czy podyplomowych, a nawet zamknięcie biblioteki dla czytelników w któryś dzień tygodnia. W $2011 \mathrm{r}$. biblioteki trzech Wydziałów UŁ: Ekonomiczno-Socjologicznego, Nauk Geograficznych i Matematyki i Informatyki były już podporządkowane organizacyjnie dziekanom tych Wydziałów, choć merytorycznie nadal pozostały pod opieką OBZ UŁ.

Liczba pracowników, bibliotek, stan księgozbioru oraz udostępnianie w BZ UŁ na dzień 31.12. w latach 1995, 2000, 2005, 2010 i 2014.

\begin{tabular}{|c|c|c|c|c|c|}
\hline Rok & $\begin{array}{c}\text { Liczba } \\
\text { pracowników } \\
\text { w BZ }\end{array}$ & $\begin{array}{c}\text { Liczba } \\
\text { BZ }\end{array}$ & $\begin{array}{c}\text { Stan księgo- } \\
\text { zbioru BZ } \\
\text { (lącznie vol.) }\end{array}$ & $\begin{array}{c}\text { Liczba } \\
\text { odwiedzin } \\
\text { w BZ }\end{array}$ & $\begin{array}{c}\text { Liczba } \\
\text { vol. lącznie } \\
\text { udostępnionych } \\
\text { w BZ }\end{array}$ \\
\hline 1995 & 101 & 70 & $783383^{a}$ & 180909 & 818159 \\
\hline 2000 & $101^{b}$ & 100 & 1044050 & 278640 & 1264165 \\
\hline 2005 & $108^{c}$ & 105 & 1053399 & $?^{d}$ & $1478234^{e}$ \\
\hline 2010 & $78^{f}$ & $91^{g}$ & $947475^{h}$ & 228454 & 848504 \\
\hline $2015^{i}$ & 66 & $84^{j}$ & 952525 & 178837 & 580351 \\
\hline
\end{tabular}

Źródło: Sprawozdania Biblioteki Uniwersyteckiej w Łodzi za poszczególne lata.

\footnotetext{
${ }^{a}$ Stan liczebny opracowanego księgozbioru; brak danych całkowitych.

${ }^{b} \mathrm{Na}$ tę łączną liczbę personelu składało się 95 osób na etatach bibliotecznych i 6 innych.

${ }^{c} \mathrm{Na}$ tę łączną liczbę personelu składały się 102 osoby na etatach bibliotecznych i 6 innych.

${ }^{d}$ Brak precyzyjnych danych.

${ }^{e} \mathrm{Z}$ ogólnej liczby udostępnień 1478234 vol. - 1433023 vol. (ok. 97 \%) udostępniło 30 bibliotek posiadających czytelnie.

${ }^{f}$ Po decentralizacji UŁ zlikwidowano dalsze 3 biblioteki, ich księgozbiory zostały przejęte przez inne, zmniejszono obsadę personelu bibliotecznego.

${ }^{g}$ Jedynie w 18 bibliotekach zatrudnieni byli pracownicy etatowi.

${ }^{h}$ Zmniejszenie stanu księgozbioru BZ spowodowany został likwidacją kilku bibliotek i selekcją zbiorów.

${ }^{i}$ Stan na 01.01.2015.

${ }^{j} \mathrm{Na}$ tę łączną liczbę 14 jednostek organizacyjnych to biblioteki zakładowe zatrudniające personel biblioteczny, zaś 70 - księgozbiory bibliotek katedralnych bez personelu bibliotecznego.
}

Główny ciężar pracy w sieci BZ ponosiły zawsze biblioteki zorganizowane według podstawowych zasad: gromadzenie, opracowanie, udostępnianie, posiadające etaty biblioteczne i czytelnie. W $2011 \mathrm{r}$. było ich $19^{25}$, z czego

${ }^{25}$ Całkowita liczba bibliotek pozostała na poziomie 2010 r. i wynosiła 91. Zob.: Sprawozdanie Oddziału Bibliotek Zaktadowych za rok 2011. 
18 pracowało $\mathrm{w}$ module katalogowania, natomiast $\mathrm{w}$ module opracowania czasopism - 10 (poza systemem pozostała Biblioteka Filii UŁ w Tomaszowie Mazowieckim). Pozostałe księgozbiory podlegały jedynie ewidencjonowaniu i pozostawały martwe dla przeciętnego czytelnika, uważane nader często za prywatne poszczególnych katedr czy zakładów.

Sukcesywnie powiększała się liczba bibliotek wdrażających moduł udostępniania, toteż w 2011 r. posiadało go już 5 jednostek. Do wymienionych wcześniej dołączyły biblioteki Wydziałów: Ekonomiczno-Socjologicznego, Prawa i Administracji i Zarządzania. Bibliotece Wydziału Nauk Geograficznych i Wydziału Ekonomiczno-Socjologicznego (w nowej siedzibie), udało się pozyskać środki na elektroniczne zabezpieczenie księgozbiorów, zainstalowanie bramek RFID i utworzenie stref wolnego dostępu.

Zintegrowany system biblioteczny Horizon został zastąpiony w 2012 r. przez aktualnie obowiązujący system Symphony. W czasie funkcjonowania wspomnianych systemów bibliotecznych systematycznie wzrastała liczba opisów bibliograficznych księgozbiorów zarówno BUŁ, jak i BZ. Podobnie rzecz wyglądała w centralnym katalogu zbiorów polskich bibliotek naukowych i akademickich NUKAT, z którym od wielu lat współpracuje BUŁ. Dzięki tej współpracy możliwe stało się szybsze dołączanie opisów bibliograficznych księgozbiorów poszczególnych bibliotek do wspólnej bazy z wykorzystaniem gotowych rekordów, ograniczone w większości do wykonania rekordu egzemplarza, bądź importu do bazy BUŁ gotowego rekordu z NUKATu. W wyniku tej operacji czytelnik bardzo szybko otrzymuje informacje o interesującym go tytule i jego lokalizacji w konkretnej bibliotece. Ma więc dostęp do kompletnych zasobów bibliotecznych w UŁ. Mimo intensywnej pracy wszystkich bibliotekarzy pracujących $\mathrm{w}$ systemie nad uzupełnianiem wspólnej bazy, użytkownicy muszą mieć świadomość, iż nadal duża część zasobów znajduje się w katalogach kartkowych.

Tabela 3

Liczba bibliotek posiadających etatowych pracowników, liczba opisów bibliograficznych i rekordów egzemplarza BZ UŁ we wspólnej bazie BUŁ na dzień 31.12. 2010 i 2014 roku.

\begin{tabular}{|c|c|c|c|}
\hline Rok & $\begin{array}{c}\text { Liczba bibliotek } \\
\text { ze stalymi } \\
\text { pracownikami }^{a}\end{array}$ & $\begin{array}{c}\text { Liczba opisów } \\
\text { bibliograficznych } \\
\text { (rekordów) ogółem }\end{array}$ & $\begin{array}{c}\text { Liczba egz. } \\
\text { w bazie ogólem }\end{array}$ \\
\hline 2010 & 18 & 18939 & 204012 \\
\hline 2014 & 14 & 15945 & 380517 \\
\hline
\end{tabular}

Źródło: Sprawozdanie Biblioteki Uniwersytetu Łódzkiego za rok 2014.

${ }^{a}$ Biblioteka Fili UŁ w Tomaszowie Mazowieckim posiada stały personel (2 etaty), lecz nie wprowadza swojego księgozbioru do systemu bibliotecznego Symphony. 
W 2014 r. doszło do kolejnych zmian organizacyjnych w sieci BZ. Wydział Filologiczny otrzymał nową siedzibę i wszystkie biblioteki funkcjonujące wcześniej w jego ramach zostały połączone w jedną, nową Bibliotekę Wydziału Filologicznego. Skomasowano więc księgozbiory dziewięciu placówek filologicznych, wyodrębniono zbiory, które zabezpieczono, zainstalowano system RFID i utworzono strefę wolnego dostępu. Z nowym rokiem akademickim 2014/2015 wdrożono moduł udostępniania dla wspólnej bazy czytelników zarejestrowanych w tej bibliotece.

\section{Ocena pracy sieci BZ UL}

Na koniec 2014 r. placówki w sieci BZ posiadały 32848 zarejestrowanych czytelników (BUŁ - 33 096), czternaście placówek pracowało w module opracowania wydawnictw zwartych systemu Symphony, dziesięć w module opracowania druków ciągłych, zaś czytelnicy siedmiu bibliotek korzystali z modułu udostępniania umożliwiającego składanie zamówień drogą elektroniczną i dostęp do osobistego konta bibliotecznego przez Internet ${ }^{26}$. Nowe możliwości, jakie dawało czytelnikom wprowadzanie kolejnych udogodnień w sieci BZ, spotkało się z dużą aprobatą użytkowników tych placówek i wychodziło naprzeciw ich oczekiwaniom i potrzebom.

Coraz częściej biblioteka bywa postrzegana przez pryzmat otwieranego dla użytkowników wirtualnego okna, toteż jej oferta powinna być na tyle atrakcyjna, by wygrać $\mathrm{z}$ innymi propozycjami $\mathrm{z}$ tego zakresu ${ }^{27}$. Zarówno BUŁ, OBZ UŁ sprawujący nadzór merytoryczny nas siecią biblioteczną, jak i placówki tę sieć tworzące, posiadające stały personel biblioteczny robią wszystko, by właśnie taki kierunek działań i organizacji pracy preferować i spełniać tym samym oczekiwania czytelników. Ponieważ opinie użytkowników determinowały najczęściej pracę poszczególnych jednostek, stąd wsłuchiwanie się $\mathrm{w}$ ich upodobania pozwalało przyjmować niezbędne rozwiązania i udogodnienia. Częstym narzędziem służącym odczytywaniu opinii czytelników są ankiety. Przeprowadzone w ten sposób moje własne badanie na grupie 104 respondentów w lutym i marcu 2015 roku pozwoliło stwierdzić, jak są postrzegane BZ i pośrednio BUŁ przez środowisko akademickie UŁ. O opinie proszeni byli studenci różnych wydziałów (odpowiedzi na ankietę udzieliło W sumie 67 studentów z 7 Wydziałów UŁ) oraz pracownicy naukowi UŁ (37 ankietowanych). W badaniu wzięli udział studenci Wydziałów (kolejność alfabetyczna):

- Ekonomiczno-Socjologicznego;

- Filologicznego;

- Filozoficzno-Historycznego;

- Geograficznego;

\footnotetext{
${ }^{26}$ Biblioteka Uniwersytetu Łódzkiego. Sprawozdanie z działalności za rok 2014.

${ }^{27}$ Małgorzata Kisilowska, Biblioteka $w$ sieci - sieć $w$ bibliotece, Warszawa 2010, s. [89].
} 
- Nauk o Wychowaniu;

- $\quad$ Prawa i Administracji;

- Zarządzania

- $\quad$ oraz 4 osoby, które nie podały danych o kierunku studiów.

Zdecydowaną większość ankietowanych stanowili studenci - 64\%, pozostała część ankietowanych wywodziła się z grona pracowników naukowych $36 \%$ (rys. 1).

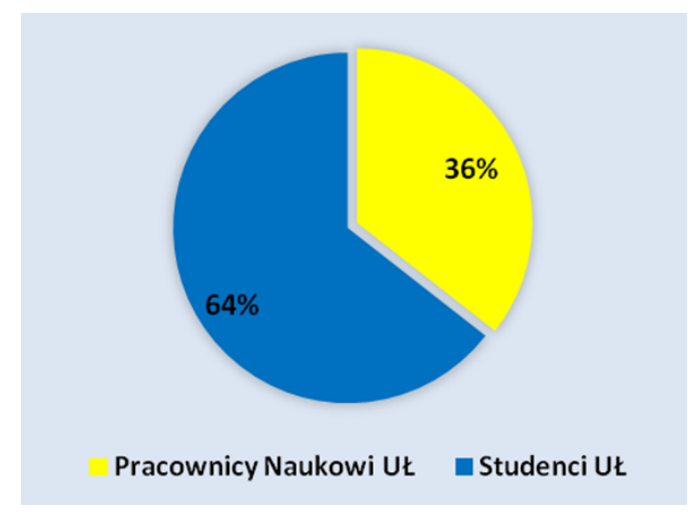

Źródło: opracowanie własne.

$$
\text { Rys. 1. Status ankietowanych }
$$

Kobiety stanowiły $58 \%$ badanych, zaś mężczyźni $42 \%$ (rys. 2). Największą liczbę ankietowanych $\mathrm{w}$ grupie studentów stanowili ci, reprezentujący IV i V rok studiów (rys. 3). Można więc wysnuć wniosek, iż ich oceny mają duże znaczenie, zważywszy na czas studiowania (rys. 4).

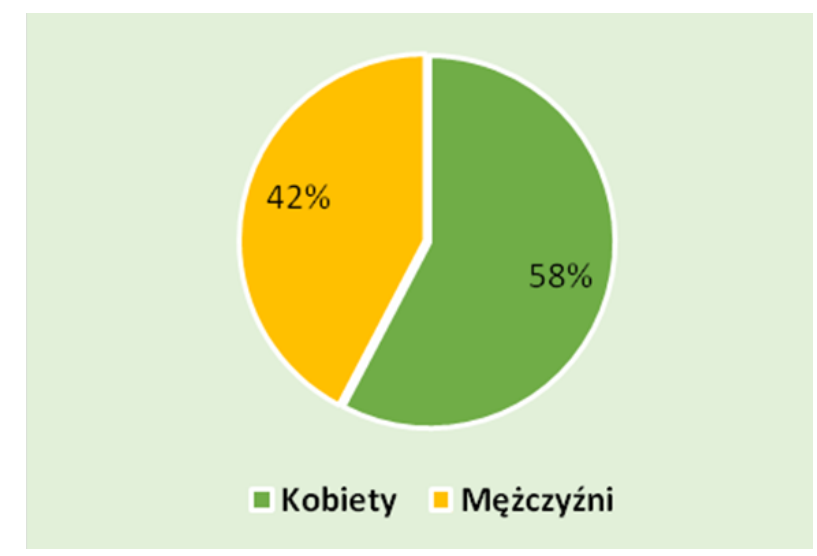

Rys. 2. Ankietowani ze względu na płeć

Źródło: opracowanie własne. 


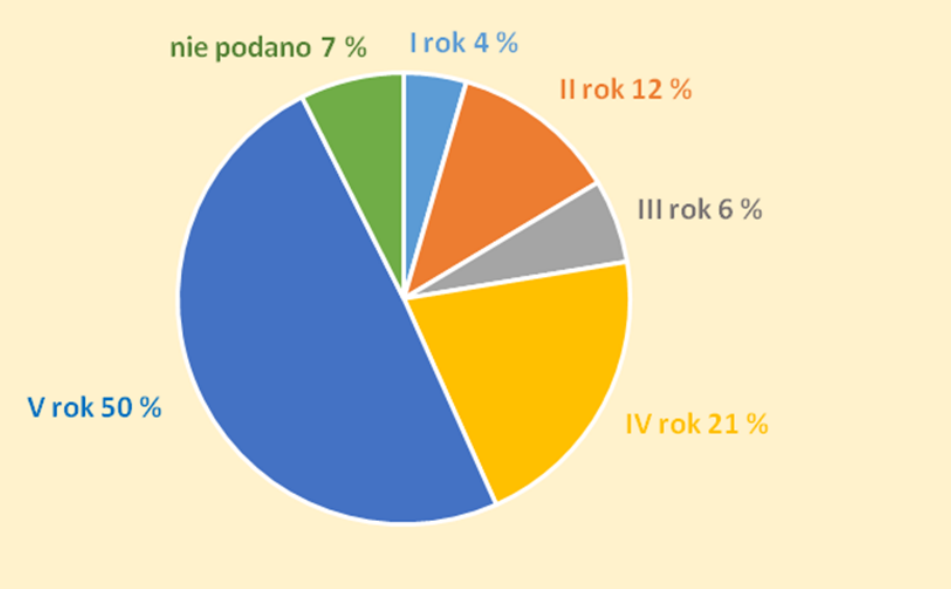

Rys. 3. Ankietowani studenci według lat studiów

Źródło: opracowanie własne.

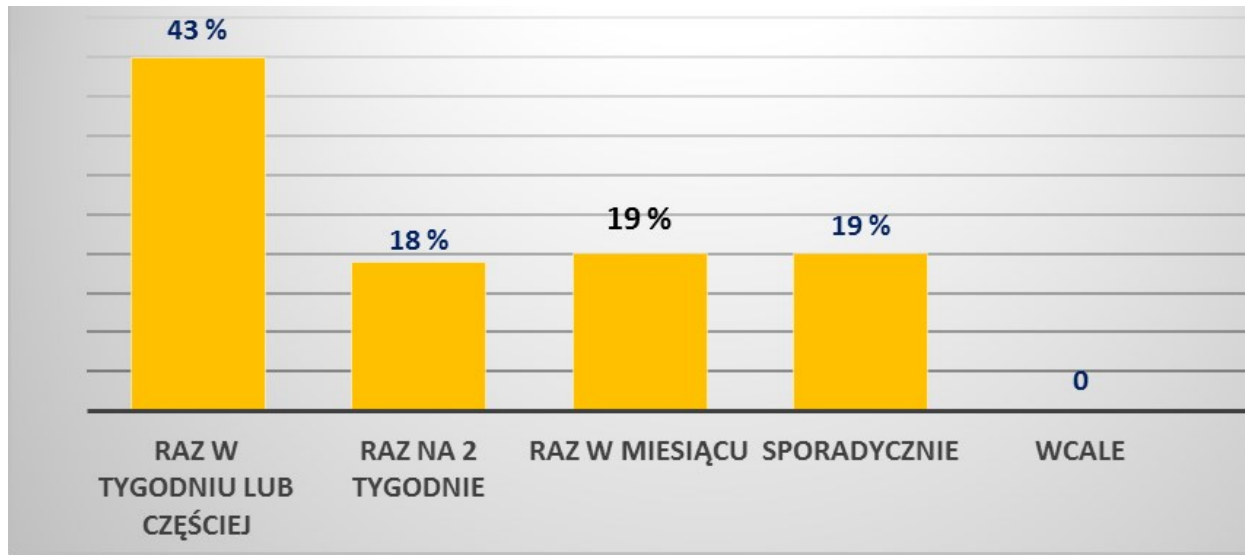

Rys. 4. Częstotliwość korzystania ze zbiorów bibliotek naukowych UŁ Źródło: opracowanie własne.

Rys. 4 pokazuje, iż największą grupę respondentów stanowili stali bywalcy bibliotek UŁ. Aż 43\% ankietowanych bywa w bibliotece naukowej raz w tygodniu lub częściej, natomiast w tym gronie nie ma nikogo, kto nie korzystałby ze zbiorów bibliotecznych w ogóle. Kolejne pytanie dotyczyło preferencji w wyborze placówek bibliotecznych. Okazało się, że zdecydowana większość wybrała BUŁ - 66\%, zaś w drugiej kolejności pozostałe biblioteki UŁ $30 \%$. Nie potrafiło sprecyzować swoich upodobań 7\% ankietowanych (rys. 5). 


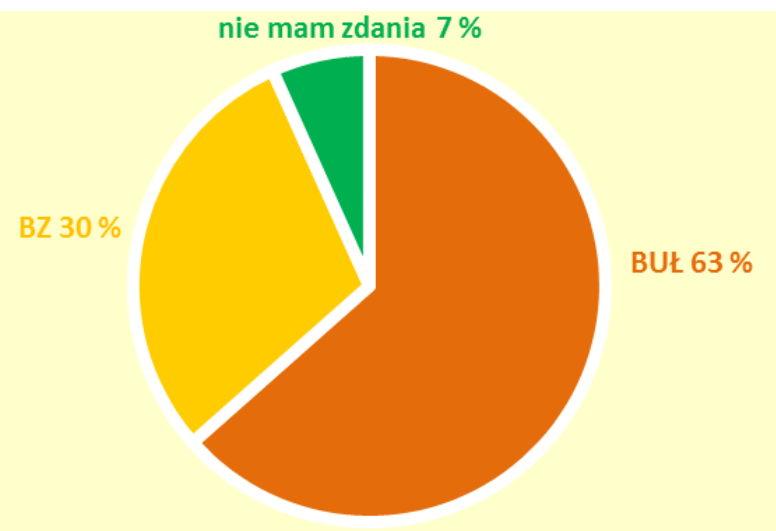

Źródło: opracowanie własne.

Rys. 5. Preferencje w wyborze biblioteki naukowej UŁ

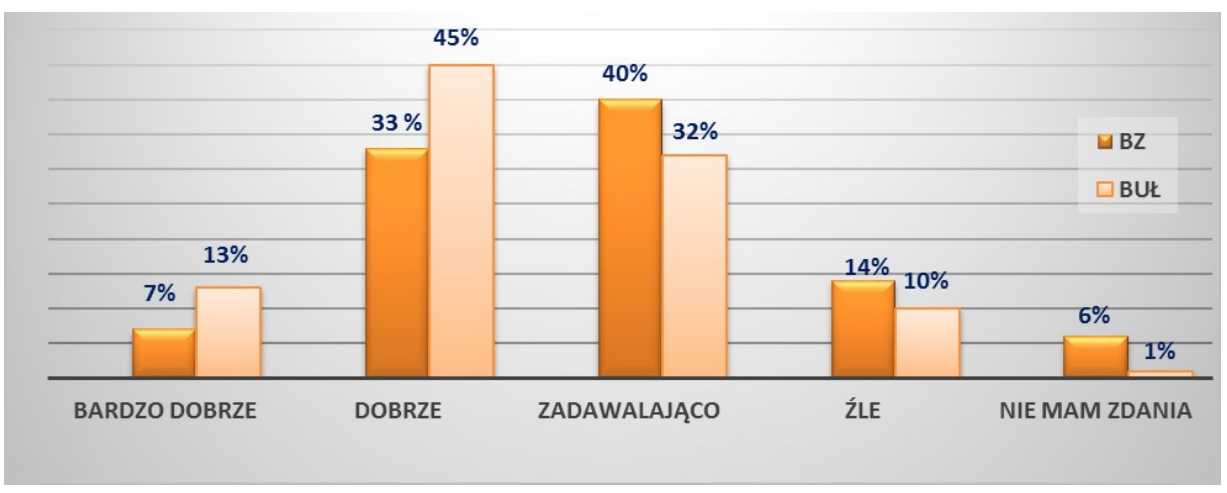

Rys. 6. Ocena zbiorów bibliotecznych BZ UŁ i BUŁ.

Źródło: opracowanie własne.

Zbiory zgromadzone w bibliotekach naukowych UŁ ocenione zostały pozytywnie. Dobrze i zadawalająco o księgozbiorach BZ wypowiedziało się łącznie $73 \%$ ankietowanych, a o zbiorach BUŁ 77\%. Najwyższą notę postawiło BZ 7\% odpowiadających, przy czym BUŁ uzyskała wynik 13\%. Martwić może liczba niezadowolonych, negatywnie oceniających zasoby zgromadzone przez BZ UŁ, na poziomie 14\% i BUŁ z 10\% niezadowolonych. $6 \%$ ankietowanych nie potrafiło ustosunkować się do jakości księgozbioru w BZ, a jedynie 1\% w przypadku BUŁ.

Końcowe pytania dały odpowiedź na temat oceny pracy bibliotek i bibliotekarzy oraz dostępności zbiorów. I w tym względzie środowisko akademickie jest raczej zadowolone $\mathrm{z}$ oferty, jaką do nich kierują wszystkie biblioteki UŁ. Zdecydowany odsetek ankietowanych pozytywnie wypowiedział się na 
temat kontaktów z pracownikami bibliotek: tak i raczej tak to $88 \% \mathrm{w}$ odniesieniu do BZ UŁ i 89\% dla BUŁ. Odpowiedzi negatywne były marginalne, aczkolwiek powinny dać do myślenia bibliotekarzom i zostać poddane wnikliwej analizie (rys. 7). Inaczej wyglądała ocena godzin pracy poszczególnych placówek. „Tak” i ,raczej tak” odpowiedziało 73\% zadowolonych czytelników BZ, natomiast aż $21 \%$ respondentów zaznaczyło odpowiedź „raczej nie” lub „nie”, a $6 \%$ nie potrafiło jednoznacznie odpowiedzieć na tak sformułowane pytanie. Lepsze oceny otrzymała BUŁ: „tak” i ,raczej tak” odpowiedziało aż 88\% pytanych, zaś negatywnie: „raczej nie” lub „nie” $11 \%$ i tylko $1 \%$ nie miało zdania na ten temat (rys. 8).

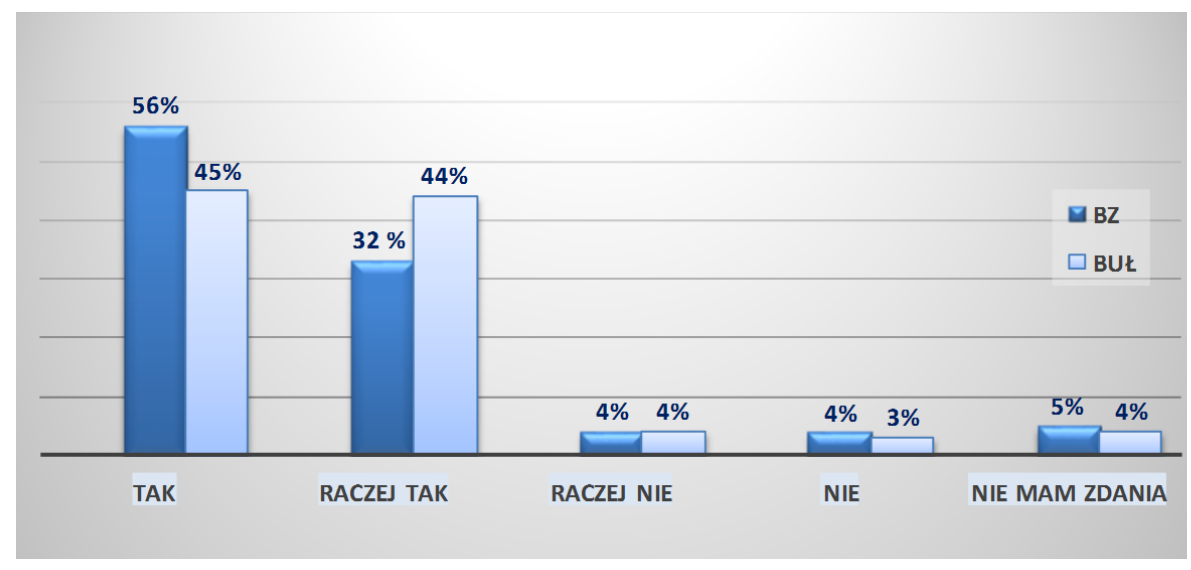

Rys. 7. Ocena obsługi czytelników w BZ UŁ i BUŁ

Źródło: opracowanie własne.

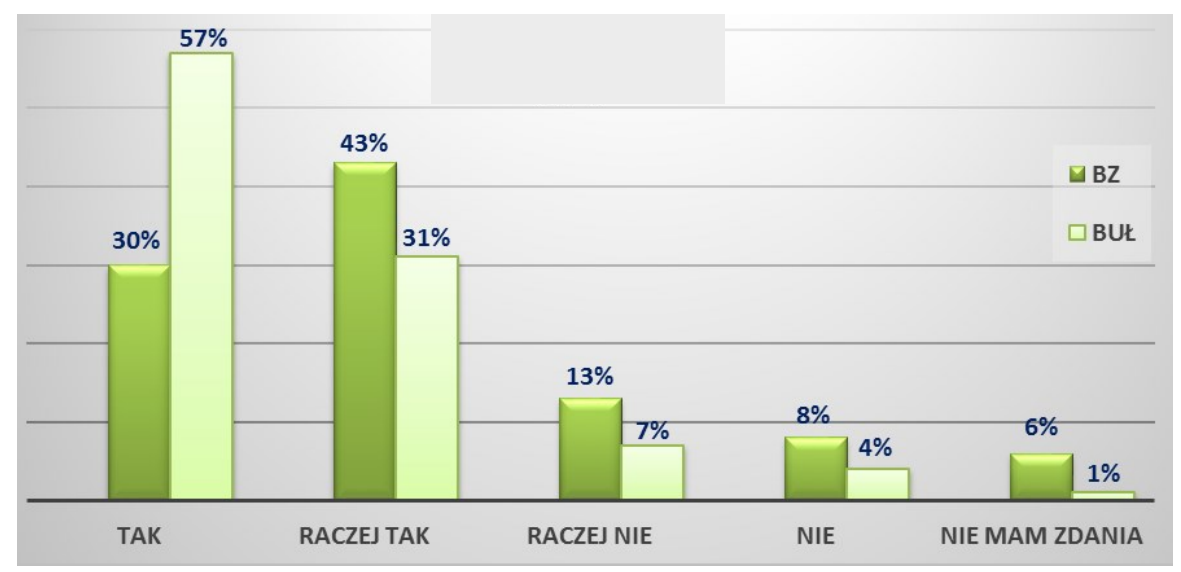

Rys. 8. Ocena czasu pracy BZ UŁ i BUŁ

Źródło: opracowanie własne. 
Tak duży odsetek ankietowanych, krytycznie ustosunkowanych do czasu pracy w sieci BZ nie powinien dziwić, gdyż przez dziesiątki lat dostęp do zbiorów specjalistycznych zgromadzonych na Wydziałach, w instytutach czy zakładach był znacznie łatwiejszy. Obecnie personel poszczególnych placówek sieci bibliotecznej został uszczuplony przez reorganizację w UŁ, a konieczność redukcji etatów we wszystkich jednostkach bibliotecznych wymusiła znaczne zmiany organizacyjne, między innymi łączenie bibliotek, czy skrócenie czasu pracy placówek. Nie wszystkie podjęte działania spotkały się więc $\mathrm{z}$ aprobatą użytkowników. Jedynie BUŁ zachowała wcześniejszy harmonogram godzinowy pracy, a nawet wydłużyła go w trakcie trwania sesji egzaminacyjnych, co wyraźnie dostrzegli w swojej ocenie ankietowani.

\section{Zakończenie}

Zadaniem sieci bibliotecznej UŁ jest współuczestniczenie w wypełnianiu podstawowych obowiązków uczelni. Zasoby BZ gromadzone są zgodnie z prowadzoną działalnością naukowo-badawczą i dydaktyczną macierzystych jednostek, z dbałością o wysoką jakość zbiorów. Praca wszystkich bibliotek UŁ we wspólnym systemie, początkowo Horizon, a obecnie Symphony, ułatwia na co dzień wprowadzanie wspólnych zasad pracy w sieci, zaś udostępnianie całemu środowisku akademickiemu księgozbiorów będących w posiadaniu placówek uniwersyteckich, przynosi duże korzyści wszystkim członkom tej społeczności.

Główną troską BZ wciąż pozostaje obsługa pracowników naukowych i studentów określonych dziedzin wiedzy i zapewnienie im najbardziej aktualnej literatury wąsko specjalistycznej w postaci druków zwartych i ciągłych, polskich i obcojęzycznych, a obecnie również elektronicznych baz online, będących najczęściej we wspólnym posiadaniu BUŁ i BZ. Niekiedy bazy finansowane w całości przez Wydziały pozostają w gestii Wydziałów i bibliotek dziedzinowych, na przykład:

HeinOnline - baza zawierająca pełnotekstowe czasopisma z zakresu prawa i dyscyplin pokrewnych. Baza subskrybowana przez Wydział Prawa i Administracji UŁ udostępniana jest na tym Wydziale.

Thesaurus Linguae Graecae - tezaurus greckich tekstów źródłowych, które ukazały się od czasów Homera do upadku Bizancjum w 1453 r. Dostęp jest możliwy w strefie wolnego dostępu BUŁ oraz w Instytucie Historii Wydziału Filozoficzno-Historycznego UŁ.

CEIC Data - gromadzi dane statystyczne dotyczące wskaźników sektorowych makroekonomicznych oraz dane finansowe $\mathrm{z}$ całego świata. Baza subskrybowana jest przez Wydział Ekonomiczno-Socjologiczny i udostępniana na tym Wydziale. Dane do logowania znajdują się u bibliotekarzy w Bibliotece WES.

Emerald Journals - kolekcja czasopism wydawana przez Emerald Group Publishing Ltd. Tematyka czasopism obejmuje takie dziedziny, jak: finanse, 
zarządzanie, ekonomia, szkolenia, biznes międzynarodowy, marketing, polityka socjalna. W ramach subskrypcji dostępna jest kolekcja eJournals 200. Subskrypcja bazy finansowana jest ze środków Wydziału Zarządzania UŁ.

Niewątpliwie BUŁ jest jedną z najnowocześniejszych bibliotek nie tylko w Łodzi, ale i w Polsce. Także przez użytkowników jest wskazywana jako bardziej atrakcyjna niż BZ (rys. 5). Nie umniejsza to znaczenia bibliotek dziedzinowych uzupełniających tematyką swych zbiorów zasoby Biblioteki Głównej. Tworzą one wraz z BUŁ sieć biblioteczną połączoną jedną bazą, wspólnym katalogiem elektronicznym, modułami katalogowania druków zwartych i ciągłych oraz udostępniania. BUŁ, jako centrala sprawująca szeroko pojęty nadzór nad BZ, wiedzie prym $\mathrm{w}$ wyznaczaniu tendencji rozwoju wszystkich bibliotek UŁ, a te doskonale wpisują się w środowisko akademickie pełniąc istotną funkcję w procesie naukowo - dydaktycznym uczelni, jako element instytucjonalny przestrzeni edukacyjnej. Jednocześnie BZ UŁ posiadają swobodę i autonomię w kreowaniu wizerunku, własnych strategii rozwoju i starannym doborze kolekcji, współpracując przy tym często z pracownikami dydaktycznymi. W większości borykają się $\mathrm{z}$ trudnościami finansowymi utrudniającymi gromadzenie nowości i własną modernizację, lecz nadal, mimo spadku czytelnictwa, mogą poszczycić się dużym stopniem wykorzystania swoich zbiorów (tab. 2). Zastrzeżenia może budzić jedynie sposób funkcjonowania, licznych w UŁ, księgozbiorów katedralnych. Nie posiadają one etatowego personelu bibliotecznego, a co za tym idzie, nie są profesjonalnie zorganizowane.

Przychodząc do biblioteki dziedzinowej, zarówno pracownicy naukowi, jak i studenci, posiadają mniej lub bardziej sprecyzowane zadania do wykonania. Często potrzebują fachowej pomocy bibliotekarzy dziedzinowych, nie tylko w zakresie dostarczenia poszukiwanego dokumentu, ale i informacji o tym, gdzie i jak można dotrzeć do wartościowych treści naukowych, pozwalających pogłębiać zainteresowania. Ważne jest więc wyedukowanie użytkowników pozwalające na wszechstronne wykorzystanie specjalistycznego księgozbioru, często unikatowego oraz niwelowanie barier i przeszkód informacyjnych. Pracownicy tych placówek dokładają wszelkich starań, by temu zadaniu sprostać. W BZ możliwa jest bardziej specyficzna relacja interpersonalna na linii bibliotekarz - czytelnik oraz bibliotekarz - współpracujący ze swoją biblioteką personel naukowo-dydaktyczny macierzystego Wydziału czy Instytutu, a także podmiotowe traktowanie użytkowników, skoncentrowane na ich ściśle określonych potrzebach i wymaganiach (rys. 7). Krótsza wydaje się też droga książki do czytelnika, zaś stopień wykształcenia pracowników BZ UŁ gwarantuje również profesjonalną obsługę czytelników. Znacząca większość zatrudnionego w BZ personelu posiada wykształcenie wyższe bibliotekoznawcze lub dziedzinowe, a niejednokrotnie skończone studia magisterskie i podyplomowe. Wszystkie wymienione wyżej argumenty dowodzą, iż sieć BZ wywiązuje się ze swojej misji, nieprzerwanie rozwija, a służąc celom naukowo-badawczym i dydaktycznym środowisku akademickiemu UŁ, nadal jest uczelni potrzebna. 


\section{Bibliografia}

Baranowski B., Baranowski K., Pierwsze lata Uniwersytetu Łódzkiego (1945-1949), Łódź 1985. Dekret o bibliotekach... z dnia 17 kwietnia 1946 r., ,Dziennik Ustaw” 1946, nr 26, poz. 163.

Historia Uniwersytetu Łódzkiego, [dostęp: 19.01.2015], http://www.uni.lodz.pl/ouni/historia .

Informator Oddziału Bibliotek Zakładowych na rok 2001, Łódź 2001.

Kisilowska M., Biblioteka w sieci - sieć w bibliotece, Warszawa 2010.

Sprawozdania Biblioteki Uniwersyteckiej $w$ Lodzi za lata 1948-1949, 1955, 1965, 1975, 19851986, 1995, 2000, 2005, 2010, 2014, Łódź 1949-2015.

Sprawozdanie Oddziału Bibliotek Zakładowych za rok 2010, 2011, Łódź 2010-2011.

Uniwersytet Łódzki (24 maja 1945 - 24 maja 2000): refleksje nad dziejami i dorobkiem Uczelni] = University of Łódź (24th May, 1945 - 24th May, 2000): reflections on the history and achievements of the University, komitet red. S. Liszewski [et al.], Łódź 2000.

Ustawa z dnia 12 września 1990 r. o szkolnictwie wyższym, „Dziennik Ustaw” 1990, nr 65, poz. 385 .

Więckowska H., Biblioteka Uniwersytecka, [w:] Materiaty do dziejów Uniwersytetu Łódzkiego (1945-1950), red. B. Baranowski, K. Duda-Dziewierz, Łódź 1952, s. 113-132.

Wskazówki dla bibliotek zakładowych U.t., [oprac. J. Racięcka przy współudziale I. Treichel], Łódź 1951.

Zarządzenie Ministra Szkolnictwa Wyższego z dnia 18 marca 1961 r., „Dziennik Urzędowy Ministerstwa Spraw Wewnętrznych” 1961, nr 3, poz. 9.

Zarządzenie Rady Ministrów z dnia 27 sierpnia 1966 r., „Dziennik Ustaw” 1966, nr 37, poz. 225. 
Załącznik nr 1. Ankieta biblioteczna

ANKIETA BIBLIOTECZNA

1. Pleć

oKobieta

oMężczyzna

2. Status na uczelni

$\circ$ Pracownik

oStudent

3. Jeśli wybrałeś student podaj

Wydział UŁ

rok studiów

4. Jak często korzysta Pan/Pani ze zbiorów bibliotek naukowych Uniwersytetu Lódzkiego (BUL, wydziałowej, instytutowej, katedralnej)

oraz w tygodniu lub częściej

oraz na 2 tygodnie

oraz w miesiącu

osporadycznie

owcale

5. Z której biblioteki w UŁ wolisz korzystać

○BUŁ

owydziałowej, instytutowej, katedralnej

$\circ$ nie mam zdania

6. Jak oceniasz zbiory BUL

obardzo dobrze

odobrze

ozadawalająco

oźle

onie mam zdania

7. Jak oceniasz zbiory bibliotek specjalistycznych UL (wydziałowych, instytutowych, katedralnych)

obardzo dobrze

odobrze

ozadawalająco

oźle

onie mam zdania

8. Czy jesteś zadowolony ze sposobu obsługi czytelnika w BUL

otak

oraczej tak

oraczej nie

onie

onie mam zdania 
9. Czy jesteś zadowolony ze sposobu obsługi czytelnika w bibliotekach specjalistycznych UL (wydziałowych, instytutowych, katedralnych)

otak

oraczej tak

oraczej nie

onie

onie mam zdania

10. Czy jesteś zadowolony z godzin pracy w BUL

otak

oraczej tak

oraczej nie

onie

onie mam zdania

11. Czy jesteś zadowolony $z$ godzin pracy $w$ bibliotekach specjalistycznych UL (wydzialowych, instytutowych, katedralnych)

otak

oraczej tak

oraczej nie

onie

onie mam zdania 